Psychology of Language and Communication 2017, Vol. 21, No. 1

DE GRUYTER

OPEN

DOI: $10.1515 /$ plc-2017-0010

ŁUKASZ K. KMIOTEK, PAWEŁ BOSKI

University of Social Sciences and Humanities, Poland

\title{
LANGUAGE PROFICIENCY AND CULTURAL IDENTITY AS TWO FACETS OF THE ACCULTURATION PROCESS
}

\begin{abstract}
This article describes a cross-cultural study comparing bicultural identity of first generation Poles and high school students in the Rhône Alpes region (France), as well as French language university students in Poland. Studies show that two components, language and identity, are related. This article intends to answer questions regarding the relationship between the migrant's bicultural identity and language proficiency. Bilingualism is operationalized as (i) listening comprehension and (ii) bidirectional translation. The results do not confirm that there is a relation between bilingual skills and identification with shared French and Polish values. Cultural identity appears to be inversely related to country of residence: Polish identity is strongest amongst immigrant youth in France and French identity is strongest amongst Polish students of French language and culture. These identities run in opposite direction to language competencies. The results suggest internalization of one of the cultures' negative stereotypes towards the other or towards itself.
\end{abstract}

Key words: acculturation, bilingualism, biculturalism, values, identity

"Naučte se nový jazyk a získáte novou duši,"

Learn a new language and get a new soul.

Czech Proverb

\section{Introduction}

From the cross-cultural and psycholinguistic standpoint, an interesting research question arises pertaining to the relationship between bilingual proficiency and the formation of bicultural identity. In this research project,

Address for correspondence: Lukasz Kmiotek, University of Social Sciences and Humanities, Chodakowska 19/31,03-815 Warszawa, Poland. E-mail: 1kmiotek@swps.edu.pl 
the authors are asking whether language proficiency is related to cultural identity formation. For the purpose of the present study, cultural identity is theoretically conceived of as the distance (similarity) between one's endorsement of cultural values and one's perception of their importance in cultures (Boski, 2006).

In the first section of this paper, empirical arguments are presented to support the claims regarding the relation between language and identity among mono and bilingual individuals. In the second section, arguments are presented to support the claim that declared preference for the values of a particular culture may lead to the learning, improvement and maintenance of the language associated with that particular culture. Research findings presented in the third section of this paper suggest that social values (perceived high social status and prestige) might lead to learning a second language.

\section{The relation between language and identity}

Wierzbicka (1997) argues that languages impose cultural constraints on their users. In other words, the acquisition ${ }^{1}$ of each language is combined with the adoption of specific ways of thinking, styles and norms of behavior, and manners of expressing our feelings. Consequently, the natural acquisition of a second language - like that of the first - involves one's inclusion into the second culture, rather than simply the assimilation of a linguistic code. Using any language implies "becoming" a member of a particular cultural group (ethnic, national or both at the same time) and involves participation in a variety of social interactions, as well as the enrichment, or sometimes the formation or redefinition of one's own identity. The use of a language ${ }^{2}(\mathrm{~L} 1, \mathrm{~L} 2, \mathrm{Ln} . .$.$) in daily interpersonal$ interactions is closely related to identity at the personal, as well as cultural and ethnic level (e.g. national pride, situational communication, attitudes and beliefs, Hamers \& Blanc, 2000). From the acculturative standpoint, communicative skills serve as an indicator of successful adaptation and adjustment. Since language and other aspects of culture (e.g. lifestyle, attitudes and beliefs, customs, values, etc.) are all intertwined phenomena, the acquisition of a country's official language(L2) during migration should have various cultural consequences for the individual. This may concern lifestyle changes (including daily practices and behaviors)in self-representation and self-construals (Markus \& Kitayama, 1991).

Cross-cultural research shows that the two cultural components, language and values, are related. When comparing monolinguals from different cultures, a link has been shown between the use of certain grammatical forms (i.e. the first person singular pronoun "I") and individualism on the individualism-collectivism cultural dimension (Uz, 2014, Nisbett \& Miyamoto, 2005; Kashima \& Kashima, 1998). Study results indicate that in collectivist cultures, languages allow for

\footnotetext{
Linguists distinguish between "language learning" and "language acquisition". The first process is teacher-led and classroom-based, whilst the second denotes spontaneous child language development (Laskowski, 2013; Laskowski, Czelakowska, \& Wiraszka, 2015; Wróblewska-Pawlak, 2014).

2 L1 denotes the mother tongue or first language, L2 denotes the second language learned after the first.
} 
dropping the singular "I" pronoun, whereas languages in individualist cultures do not allow pronoun dropping.

Using the TST (Twenty Statement Test), Cousins (1989) showed the independent self to be related to the use of adjectives and the interdependent self to the use of nouns. This path of research has been continued in political psychology, demonstrating links between grammatical parts-of-speech use and the worldview or specific ideology ascribed to by the speaker (Cichocka, Bilewicz, Jost, Marrouch,\& Witkowska, 2016). Results of the research show a correlation between socio-political conservatism and (i) a preference for nouns in the Polish language; (ii) a preference for nominal sentences in Arabic (sentences composed of nouns or a noun and an adjective in which the verb is implied); (iii) a higher proportion of nouns in the speeches of Republican presidents compared to those of Democratic presidents in US English. As the authors explain, "Nouns convey greater permanence, stability of subjects and objects, as well as categorical perceptions of social actors and the world at large. As such, they are likely to address conservatives' greater needs for order, certainty, and predictability."

The monocultural/linguistic framework may be extended to bilingual/ cultural analysis. Here, the best known example is the cultural frame switching and parallel linguistic code switching paradigm (Benet-Martínez, Lee,\& Leu, 2006; Benet-Martínez, Leu, Lee, \& Morris, 2002; Chen, Benet-Martínez, \& Bond, 2008; Pavlenko \& Blackledge, 2004). This paradigm assumes that with a linguistic switch, bilinguals change their cognitive style or value preferences to the characteristic of a primed culture. Benet-Martínez et al.(2002) proposed the Bicultural Identity Integration Model (BII) which defines the switch between two cultures as a way of responding adequately to situational demands. Well-adapted bicultural/bilingual individuals seem to be able to switch their cognitive functioning harmoniously and congruently from culture A to culture B or vice versa, depending on which culture's symbols are presented. The use of the code switching mechanism in daily interpersonal interactions enables negotiation of an individual's dual (hyphenated) identity. A paradoxical switch occurs for individuals whose bicultural identity is conflicted. They respond with the cultural identity opposite to that which was primed.

Based on the code switching paradigm, Boski \& Iben Youseff (2012) extended the evidence from the purely cognitive to the axiological domain by studying two generations of Arabic-French bilingual Tunisians. Participants were asked questions pertaining to values entrenched in their cultural milieus and about values reflecting their personal convictions. The authors tested to what extent the bilinguals endorsed two sets of cultural values: Arab-conservative (i.e. conformity, family, tradition, honor and goodness) and French-autonomous (i.e. hedonism, life quality, freedom, equality, subjectivity, universalism and reason). The findings demonstrated that individuals examined in Arabic declared Arab values as more central in their family environment and endorsed them to 
a greater degree than respondents examined in French. On the other hand, those tested in French reported more conflict between environmental pressures and their own personal preferences. The study demonstrated that certain cultural concepts or values can only be expressed in the language to which they correspond. Otherwise, what occurs is a "lost in translation" phenomenon (Wierzbicka, 1997). These findings ascertain that bilingual individuals, who are users of two systems of meaning also have two systems of values, that change depending on which culture is activated (Bond, 1983). The study provides empirical evidence for the influence of language on the use of values as life-guiding principles among the bilingual Arab population of the Maghreb.

This model of analysis and interpretation can also be applied to the study of Polish immigrants, who are in the process of acquiring a new language and retaining their first language. In the present study the Polish-French profile is assessed. We expect that bilingual proficiency increases in correspondence to identification with the activated cultural system.

Consequently, and in line with findings discussed above, we speculate that value acquisition should be regulated by language proficiency (bilingualism). In other words, communicative skills should influence value internalization and identity among monolinguals and bilinguals- to the extent that they have mastered both languages. With improved linguistic skills, there should be increased identification with the corresponding cultures.

However, an alternative path of causality, from values to language learning and competence is also plausible. The following section will concern the influence of ethnic values on ethnic language learning improvement and maintenance.

\section{The influence of values on language learning}

The decision to learn an ethnic language may stem from identification with certain values, perceived as salient, distinctive cultural characteristics. In such a case, a sense of belonging to the cultural group (ethnic identity) is not supported by language proficiency but may lead to its acquisition. This happens when a language forms into a core value- an element perceived as a salient, crucial and distinctive characteristic of cultural identity (Smolicz, 1981, 1999). This phenomenon was observed by Miodunka (2003) who explored Polish-Portuguese bilingualism in Brazil. The study findings present the relation between the participants' self-assessment of Polish language use and the knowledge of the Polish lifestyle, customs and cultural traditions. The use of Polish in traditional social roles (e.g. parent-child dyads) and institutions (e.g. folkloristic groups) has resulted in transmission of the Polish way of life, social norms and "unconscious" ethnicity to the younger generations. These results support the claims that Polish-Portuguese bilingual individuals identify equally with the two cultures.

The willingness to learn Polish is observed among Polish repatriates from post-Soviet Republics (e.g. Kazakhstan, Asiatic part of Russia). Here, young 
individuals possessing knowledge about Polish culture and traditions (Christmas tree, St. Nicholas bringing Christmas presents, the blessing of Easter baskets, Wet Monday after Easter), and traditional Polish meals (chicken noodle soup, pierogi, pączki [a type of doughnut], borsch, and black pudding) declare attachment to traditional Polish values, including Catholicism. These descendants of Polish citizens (forced by Soviets during World War II to expatriate, Herling, 1996), demonstrate high motivation to learn Polish. Meanwhile, Boski (1992) found that descendants of Polish migrants in the U.S. (second and third generation) had completely lost their ancestral language even though their values remain embedded in Polish culture.

\section{Acculturation, cultural identity formation and language: the deficit of research}

This section intends to demonstrate Boski's $(2008,2009)$ approach which serves as the theoretical and methodological basis for the present study. Here, language is a factor implicated in the migrant's psycho-cultural adjustment to a new environment. The cultural model of acculturation assumes that the two factors-language proficiency and culturally specific values and scripts of behavior that shape one's cultural identity - are equally implicated in the acculturative process. L2 proficiency is a vehicle of the acquisition of cultural knowledge; consisting of behavioral scripts, functional competencies, social roles and functions (hierarchy and gender). An individual adapts to the new environment by acquiring the tools by which his or her behavior becomes meaningful to others. The language of the country of settlement is the fundamental vehicle of that shared meaning. On the individual level, communication skills enhance and facilitate interaction with the local people.

Boski's $(2008,2009)$ framework assumes that integration is the merger or the third value (see: Table 1). If behavioral scripts overlap in two cultures (e.g. French and Polish: "Men are courteous gentlemen towards women; females expect males to be gentlemen who treat women with courtesy"), there are no value conflicts or competence dissonance and individual's conduct being undistinguishable can easily be adopted. If one acculturates to a second environment for a sufficiently long time, the outcome is a fusion of constituent elements. Those elements can be perceived as shared value (e.g. "Parents encourage their children to stand on their own feet and be independent from a young age"). 
Table 1.Culture description framework: perception of French and Polish values and practices in a $2 \times 2$ taxonomy

\begin{tabular}{lcc}
\hline Culture A (PL) & \multicolumn{2}{c}{ Culture B (FR) } \\
& Yes & No \\
\hline Yes & Integrated Set & Distinct Culture (PL) \\
& $\{$ PL*FR $\}$ & $\{\sim \mathrm{FR} * \mathrm{PL}\}$ \\
No & $\{1 ; 1\}$ & $\{2 ;-1\}$ \\
& Distinct Culture (FR) & Neither of the two \\
& $\{\mathrm{FR} * \sim \mathrm{PL}\}$ & $\left\{\sim \mathrm{FR}^{*} \sim \mathrm{PL}\right\}$ \\
& $\{-1 ; 2\}$ & $\{0 ; 0\}$ \\
\hline
\end{tabular}

Note: The content of this table illustrates a distribution of a set of values and cultural practices between any two cultures. It is assumed that four logical classes represent joint present and absent, as well as culture A and B specific subsets. Example: Highly valuing close, long-term friendships and caring for them. A study participant having experience with both cultures may decide on the placement of this item in one of the four logical cells. Assuming the item pool of a test is $N$, then the class capacity of each of the four subsets is the number of items falling in that cell. For instance, for integrative subset, $\mathrm{CS}_{\text {Int }}=\sum\left\{\mathrm{A}_{\mathrm{i}}^{*} \mathrm{~B}_{\mathrm{i}}\right\}$; where $\mathrm{i}=\{1, \ldots, \mathrm{n}\}$.

\section{Current research}

The present study aims to examine two components of biculturalism: linguistic skills and cultural identity. The authors of the study ask how the two components are interrelated in the French-Polish acculturative context. In the current research, two psychometric scales are applied in order to assess language skills: listening with comprehension and bidirectional translation. The aim is to explore whether the increase in bilingual skills (oral comprehension and bidirectional translation) is accompanied through value embedment from the two cultural environments. In line with the code switching paradigm introduced and discussed before (Benet-Martínez et al., 2002; Boski \& IbenYouseff, 2012) language activation triggers endorsement of values relevant to the corresponding culture. We assumed that bilingual Poles are the carriers of two systems of meaning (Polish and French) containing different values.

Research questions refer to the (1) bilingual language proficiency, (2) bicultural identity, and their relation amongst three group of respondents:

(i) first generation immigrants, (ii) secondary school students in Lyon and (iii) French language university students in Poland.

Regarding the languages we asked:

1: Will Polish individuals whose scores are higher in Polish language identify more strongly with the values that they view as corresponding to the Polish culture? Respectively, will individuals whose French language scores are 
higher identify more strongly with the values that they view as corresponding to the French culture?

Concerning cultural identity we asked:

2. Does the identity differ according to acculturative category (respondent group)?

2.1 Will the Polish cultural identity score of French language students in Poland be higher than their French cultural identity score?

2.2 Will the French cultural identity score of Polish migrants (first generation and secondary school students) in France be higher than that of the French language students living in Poland?

And finally, concerning the link between cultural identity and language proficiency:

3. Is there a correlation between one's language proficiency score (Polish, French) and the corresponding cultural identity index?

\section{Methods}

\section{Participants}

Our sample $(N=169 ; 145$ females $)$ were split into three groups: Group I, first generation immigrants $\left(N=50,42\right.$ females, $M_{\text {age }}=35.5$ years $)$; Group II, migrant CSI students $\left(N=40,30\right.$ females, $M_{a g e}=17.3$ years $)$; Comparative Group III, French language students from a Polish University ( $N=79 ; 73$ females, $M_{a g e}=21.0$ years). The years of contact with the two languages was divided by age to count the percent of one's lifetime exposure to L1 and L2 (see: Table 2).

Table 2. The percent of one's lifetime contact with Polish and French language

\begin{tabular}{lcccc}
\hline & Polish & French & N (\% of women) & $\boldsymbol{M}_{\text {age }}$ \\
\hline Group I (I Generation in FR) & 97 & 41 & $50(82.4)$ & 35.5 \\
Group II (High school stud. in FR) & 99 & 73 & $40(75.0)$ & 17.3 \\
Group III (Students in PL) & 97 & 24 & $79(92.4)$ & 21.0 \\
\hline
\end{tabular}

Note: If a migrant aged 35 declares having 35 years of direct and continuous contact with the Polish language and 18 years with French, the percent of lifetime exposure is respectively: 100 for Polish and 54 for French.

The socio-economic status of participants from Group I was diverse. Men predominantly worked in building construction (flooring, plastering, wall painting or plumbing). Women were employed in the administration sector (as translators, language teachers and/or educators) or in social services (individual care for residents of nursing homes, home aid). At least one year of stay in France was required to take part in the study. The majority of 
the study participants represented the last emigration wave, starting from 2004, the year when Poland became an EU member state and new job opportunities were opened to Polish citizens. Thus, the time spent abroad varied from one year to fourteen years, and the reasons for emigration were mainly economical. Only a fraction of the sample (7 individuals, 14\%) emigrated to France before 1989. All study participants declared regular visits to Poland for family events (weddings, Christmas, Easter, etc.).

Group II was recruited from the International School "Cité Scolaire Internationale de Lyon, CSI" and a Polish school (Daszczuk, 2012; Matczak, 2008). The Polish school is a public educational institution. It educates children from primary, through middle, to high school level. CSI has been an international educational institution since 1995, and it houses a Polish section. Other sections are English, Spanish, Italian, German, Portuguese, Chinese and Japanese. Matczak (2008) observed a growth in the number of students attending CSI, especially after 2004. 127 students (primary and secondary level) were enrolled in the Polish section in 2010/11, 120 students in 2008/2009, and 92 students in $2006 / 07$. In the academic year 2010/11, 48\% of students originated from mixed families, while $52 \%$ of students originated from both Polish parents.

According to Laskowski (2013), between 700-800 thousand Poles lived in France in 2008. In 2011, the French National Statistics Bureau (INSEE) estimated the number of Poles in France at 93 000, while in 2012 the number given by Eurostat was 350 000. The discrepancy between these estimations makes the base number of Poles in France only approximate. Apart from that, we also observed a lot of cross-border, temporary migrations.

We assumed that inclusion of a group with direct and continuous contact with the French language in Poland into the study might shed more light on the relation between language and identity. Thus, a comparative group (Group III) was recruited from the University of Wrocław in Poland. Study participants included first, second and third year (bachelor degree) students enrolled in the French language program.

\section{Procedure}

Participation in the study was voluntary and anonymous; confidentiality was provided to encourage honest responding. Participants were recruited through French-Polish associations, which serve as the migrants' institutional support, Polish Catholic Mission and Polish Consulate. The questionnaires were administrated and completed in a quiet classroom. Participants also reported demographic data including age, gender, nationality, length of residence and education level. Instructions were given at the beginning of the session. 


\section{Instruments}

Two data gathering instruments were used in the study: (1) Cultural Values and Scripts Questionnaire (CVSQ, Boski, 2006, 2008, 2009), and (2) the Polish-French bilingual proficiency questionnaire, which is composed of two parts: (i) oral comprehension and (ii) bidirectional translation. We shall briefly describe the two research instruments.

The CVSQ was initially prepared in Polish. The French version was created by a French-Polish bilingual and bicultural person, whose mother is Polish and father is French, and who has spent many years in the two countries. The two versions of the questionnaire were then translated back into Polish by a French language teacher residing in Poland and highly proficient in both languages. The final stage of verification took place in France by two Polish-French bilinguals, one of whom is a teacher of Polish language living permanently in Lyon. During the study participants could choose which version of the CVSQ to take: French or Polish.

The CVSQ contains 39 items adapted to two generations of participants. A 39 item pool was selected from the original questionnaire, which is 66 items long (Boski, 2009, p. 409). All items were formulated in terms of specific and context-loaded cultural values in two languages: French or Polish. The tool was designed in two interdependent parts: (1) locative aspect (cultural perception) and (2) evaluative aspect (value endorsement). Cultural perception is measured in a 2 x 2 table (Table 1). We ask, "To what extent does each individual perceive the two cultures he/she participates in as similar or distinct?". Item example would be, "Being an optimist by nature, waking up with new hope for a better future every day"- Is this value Polish or French, neither or both? If only PL, then the score is $(2:-1)$; if only FR, then the score is $(-1: 2)$; if both $(1: 1)$; if neither (0:0); (see: Table 1).

Next, we asked about personal endorsement of these cultural values(e.g. "I am an optimist by nature; I wake up with new hope for a better future every day"). The participants answered from -2 to 2: strongly disagree, disagree, I don't know, agree, strongly agree - depending on the level of personal identification.

Cultural identity is theoretically conceived of as the distance (similarity) between one's endorsement of cultural values and one's perception of their importance in the cultures (Boski, 2006).

This can be computed in two ways:

(1) Two components: Aggregated Polish vs. Aggregated French.

Here, we multiply the cultural perception score (a pair of values, e.g. $\{-1 \mathrm{PL}: 2 \mathrm{FR}\})$ for each item by the personal endorsement score.

For example, if a participant decides that the statement (item) "Being an optimist by nature..." describes only the French culture (and not Polish) and strongly agrees with it, then we will obtain the formula: \{-1PL: 2FR $\} \times 2=\{$-2PLId: 4FRId $\}$. The result is the individual participant's 
aggregate score for this item (Boski, 2008; 2009). To obtain the participant's total aggregate Polish and total aggregate French scores, we add up all of their aggregated scores(taken from items $1-39$ ).

(2) Four partial components (the second way):

Integrated (both Polish AND French) vs. Distinctly Polish vs. Distinctly French vs. Neither Polish nor French (Exterior). Here, for every participant, we first assign items 1-39 to the categories listed above, based on the answers that the participant gave in the cultural perception part of the questionnaire. For example, if the respondent categorizes an item (e.g.: "Being an optimist...") as "distinctly French", then FR=1, PL=0, BOTH=0 and NEITHER=0.

Then, if the respondent strongly agrees with the statement, giving it 2 points, we will obtain a formula: $\{\mathbf{1 F R}\} \mathbf{x} \mathbf{2}=\{(\mathbf{2})\}$. This yields the individual participant's distinctly French identity.

To obtain the participant's total French score, we add up all of the items that were categorized as distinctly French. For each of the remaining components we proceed in the same manner.

Polish-French Bilingual Proficiency Questionnaire. Listening with understanding. In part one (Listening), there were two conversations chosen for research purposes: one in French and another in Polish (Burkat, Jasińska, Szymkiewicz, \& Małolepsza, 2008). Participants listened twice to the recordings.

The French recording was a conversation between an arguing couple invited to a wedding ceremony who came late to the event. Eventually, after they have arrived, the woman expresses her wish to catch the veil ${ }^{3}$ (which in her opinion should motivate her partner to marry her, as they have been a couple for a long time). The Polish recording is a spoken account of a police officer questioning the witness of a car accident.

The study participants responded to eight true/false questions and they scored 1 point for each correct answer (French example: "La femme veut que Paul tourne à droit", "The woman wants Paul to turn right"; Polish example: "Mężczyzna spacerowat po parku w chwili zdarzenia", "The man was walking in the park at the time of the event").

Translation. The second part consisted of a two way text translation: (i) from French to Polish, (ii) from Polish to French (see: endnote). The texts were retrieved from the textbook "AlterEgo 4" (Dollez \& Pons, 2014). The French text talked about an individual living with his family in a workingclass $\operatorname{area}^{4}$. As a green party supporter, he is actively engaged in promoting

\footnotetext{
3 The custom called "oczepiny" epitomizes the traditional Polish wedding reception ceremony. At midnight, the bride and groom perform a special task: sitting on chairs with their eyes closed, they each have to throw, respectively: the veil and bow-tie. It is said that those who catch these items are believed to get married within one year. The throwing of the veil and bow-tie represents the final custom in a sequence of events, following which the couple are considered as married.

4 "Une quartier populaire"- this French term exemplifies the fact that words have their cultural and historical background, and in this case, political connotations, which might be lost in translation. The term evokes the commonly known tripartite French motto Liberté, égalité, fraternité, and based upon the fight for social justice and against economical inequalities. The term is one of the most challenging expressions to translate.
} 
an ecology-friendly lifestyle. The Polish text is a brief letter written by a graduate student, who interns at a television station, to a friend. She appreciates the egalitarian work environment.

Evaluation of the translated text is based on scoring linguistic errors from four categories within the target text: 0.25 for spelling, repetitions, punctuation marks; 0.5 for omission of single elements from the sentence structure; 0.75 for grammar, semantic, lexical, idiomatic or loan translation mistakes; 1.0 change in the meaning of the whole phrase; the whole phrase is missing. In other words, the worse the translation by the participant, the more points were attributed to it (an example of a French to Polish semantic error: „, Mes engagements veulent contribuer à la” "translated as „, Moje zaangażowanie może uczestniczyć” instead of ,, Moim zaangażowaniem pragne wptyną́ na”. An example of Polish to French semantic error: „Mój szef” translated as „Mon propriètaire" instead of „Mon patron"; more detailed examples of committed errors and their evaluations are provided in Annex A). The table below presents the correlations between the two tools used for assessing language skills. Table 3 presents correlations between results obtained from the two language assessment scales. The two translation method subscales were positively correlated. Surprisingly, they were negatively correlated with one oral comprehension scale (listening in French).

Table 3. Correlations between results obtained through the listening and the translation method of bilingual assessment

\begin{tabular}{lcccc}
\hline & Listening FR & Listening PL & PL $>$ FR & FR $>$ PL \\
\hline Listening FR & - & - & - & - \\
Listening PL & .07 & - & - & - \\
PL $>$ FR & $-.25^{* *}$ & -.06 & - & - \\
FR $>$ PL & $-.30^{* *}$ & .11 & $.47^{* *}$ & - \\
\hline
\end{tabular}

** The correlation is significant at the 0.01 level (2-tailed).

\section{Results}

\section{Language Proficiency}

To test the first group of our research questions concerning the impact of acculturative category on language proficiency (listening comprehension), a two-factor analysis of variance (multivariate repeated measures - MANOVA) was carried out. The study was designed in a $2 \times 3$ format: listening comprehension (FR vs. PL as repeated factors) by Groups (I vs. II vs. III). The interaction effect between the two variables, language (listening comp.) and generation, was significant $F(2,167)=18.50, p<.001, \eta^{2}=.18$, (see: Fig. 1). Compared to other groups, CSI students (Group II) had the highest French language proficiency scores, operationalized as results of the listening comprehension test $F(2,167)=19.45, p<.001, \eta^{2}=.19$. 


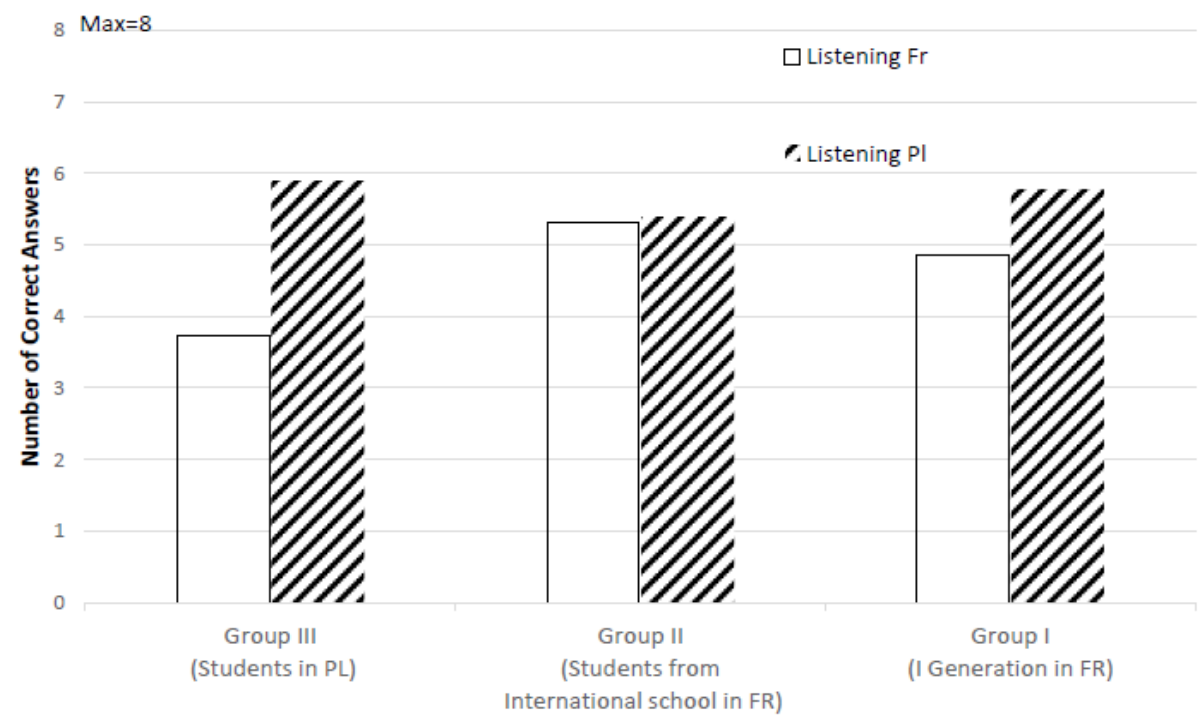

Figure 1. Bilingual proficiency rates (Listening) among French language students in Poland and migrants in France.

For group II, the statistical difference of French vs. Polish oral comprehension skills was not significant $F(1,167)=0.06, p=0.79$.

On the oral comprehension scale (French and Polish), the high school students in France scored: $M_{F r}=5.32, S D=1.16 ; M_{P l}=5.40, S D=1.54$, compared to first generation migrants: $M_{F r}=4.86, S D=1.77 ; M_{P l}=5.78, S D=1.48$; and the students in Poland: $M_{F r}=3.72, S D=1.32 ; M_{P l}=5.89, S D=1.22$.

This pattern of results suggests balanced comprehension skills among the CSI students (group II). In group I (first generation of migrants) and French language students in Poland (group III), Polish language prevailed over French.

When it comes to Polish language listening comprehension skills, the statistical analysis did not reveal any statistical differences; students in Poland scored non-significantly better than second and first generation migrants $F(2,167)=1.72, p=.18$.

To answer the research question of the impact of acculturative categories on language proficiency (bidirectional translation), a two-factor analysis of variance (multivariate repeated measures - MANOVA) was carried out. The study was designed in $2 \times 3$ format: Translation (Polish $>$ French vs. French $>$ Polish as repeated factors) by Groups (I vs. II vs. III). The interaction effect between two variables, language (Translation) and generation, was significant $F(2,164)=10.91, p<.001, \eta^{2}=.11$, (see: Fig. 2). For the bidirectional translation the simple effect was significant for group III $F(1,164)=39.74$, $p<.001, \eta^{2}=.20$; and for group II $F(1,164)=41.05, p<.001, \eta^{2}=.20$, but not for group I $F(1,164)=0.26, p=.60$. The participants forming groups II and III translated the French text to Polish better. CSI high school students 
and first generation migrants exhibited balanced bilinguality respectively in listening comprehension $F(1,167)=0.065, p=.79$, and bidirectional translation $F(1,164)=0.26, p=.60$. In the two groups (the first generation of migrants and French language students) the correctness of French to Polish translation was better than in the opposite direction.

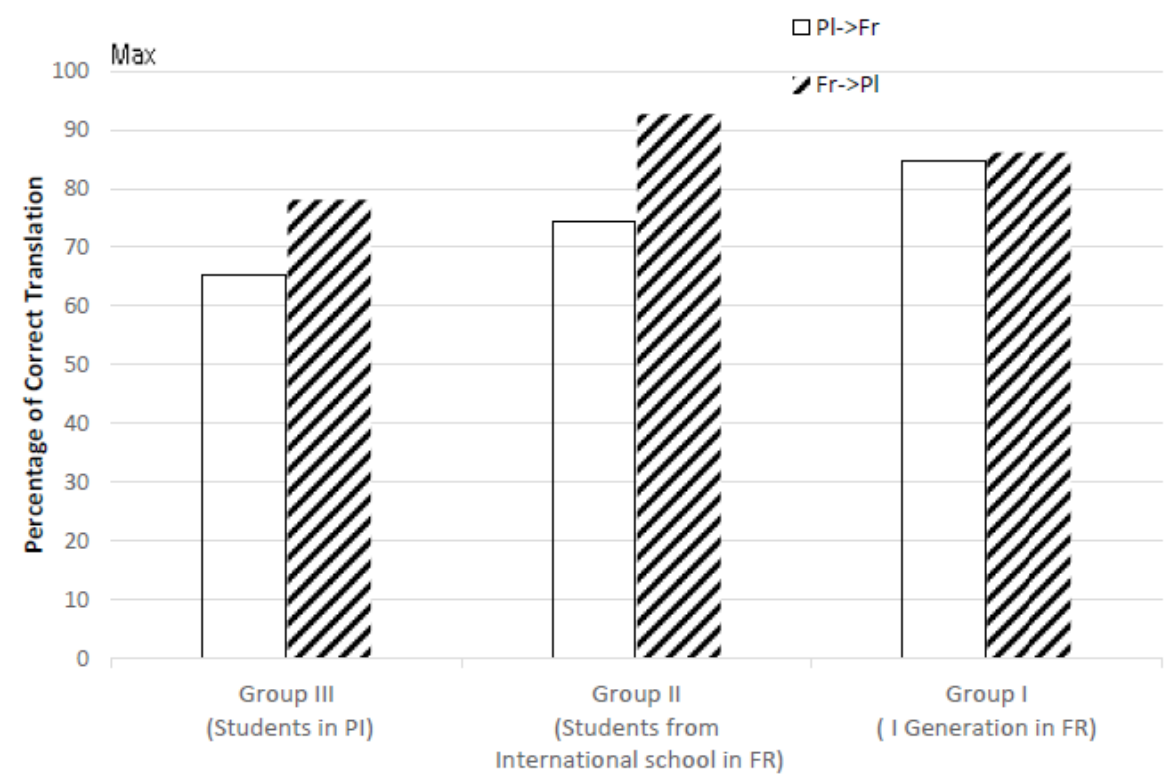

Figure 2. Bilingual proficiency rates (bidirectional translation) among French language students in Poland and migrants in France.

\section{Cultural Identity}

In the theoretical part, the procedure of transforming the raw results from the CVSQ into cultural identity indices was discussed (see: Table 1). This part presents the cross-cultural comparison between $(a)$ two cultural identity indices: aggregated Polish vs. aggregated French, and, (b) four partial identity indices: Integrated vs. PL vs. FR vs. Neither PL nor FR.

To answer research questions concerning the impact of acculturative category (adults vs. CSI students vs. students in PL) on identity dynamics, a mixed model of analysis (MANOVA) was carried out. The study was designed in a $2 \times 3$ format: Cultural Identity indices (FR vs. PL) by Groups (I vs. II vs. III). Figure 3 presents the cultural identity profile.

Dependent variables were the two identity components. A significant interaction effect between identity and type of group was found $F(2,167)=6.78$, $p<.001 ; \eta^{2}=.07$, (see: Fig. 1). 
The interaction effect between identity indices (a derivative of the two: cultural perception and personal endorsement of values) and groups indicates that Polish students with French language identify more strongly with the French culture than the first generation and CSI students in France $F(2,167)=$ 4.36, $p<.001, \eta^{2}=.05$. The same students identify with the identity measures they consider Polish to a lesser extent than the Polish migrants in France $F(2,167)=8.41, p<.001, \eta^{2}=.09$ (see: Fig. 3). Secondly, the highest Polish identity indicators appear in the group of CSI students living in France $F(2,166)=8.96, p<.001, \eta^{2}=.10$; while the French identity is highest among students in Poland, $F(2,167)=3.12, p=.01, \eta^{2}=.04$, (see: Fig. 1).

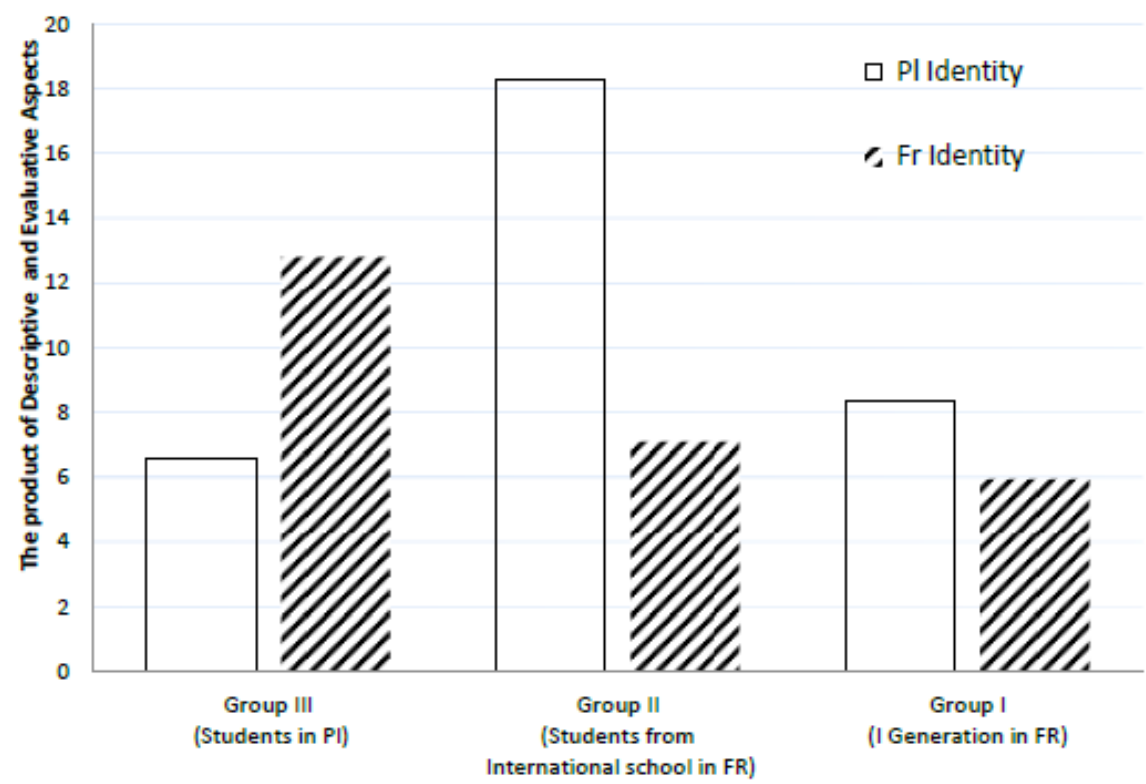

Figure 3. The two cultural identity components among French language students in Poland and migrants in France.

For the identity indices, the simple effect was significant for group II $F(1,167)=7.82, p<.001, \eta^{2}=.04$; and for group III $F(1,167)=5.23, p=.02$, $\eta^{2}=.03$, but not for the first generation $F(1,167)=0.60, p=.40$. The integrated identity (both: PL - FR) is the strongest in all three groups. French language students in Poland had the lowest score in the category "Polish distinct" (see: Fig. 4).

This pattern of discrepancies in identity scores between the groups of migrants and Polish students of French in Poland seems to indicate that the country of residence (living abroad vs. in the country of origin) is not the sole factor determining the individual's cultural identity. These differences may exist because the participants belong to different acculturative categories, but more importantly the younger participants had had earlier contact with the French 
language and culture as children. Also, the older participants were economical migrants and as a result they might have been more concentrated on practical issues, as opposed to mastering the language and cultural belongingness.

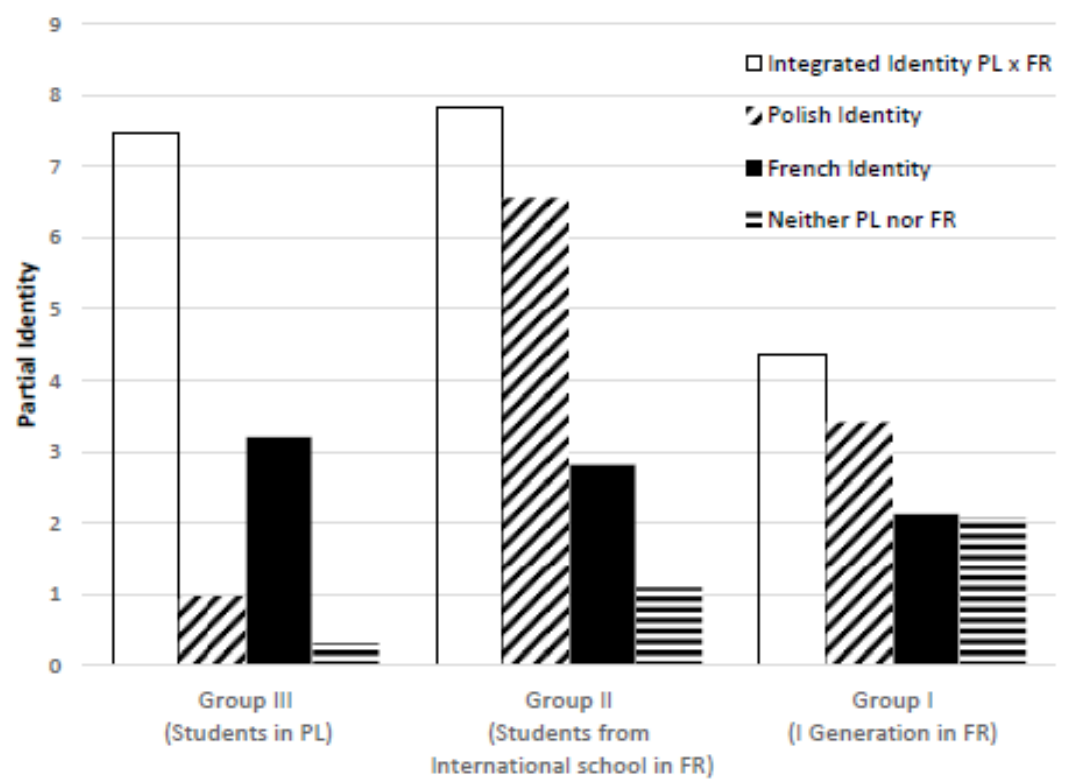

Figure 4. The four cultural identity components (Integrated vs. French vs. Polish vs. Exterior) among French language students in Poland and migrants in France

To test the research question concerning the impact of acculturative category (Group I vs. Group II vs. Group III) on identity dynamics, a mixed model of analysis (MANOVA) was carried out. The study was designed in a $4 \times 3$ format: Identity (Integrated vs. Distinct PL vs. distinct FR vs. Neither PL nor FR) by Groups (I vs. II vs. III). Dependent variables were the four cultural identity indices: Integrated vs. distinct Polish vs. distinct French vs. Neither of the two. Figure 4 graphically presents the four mean (partial) identity scores of the three groups of respondents.

A significant interaction effect between cultural identity and type of group was found $F(2,163)=4.39, p<.001, \eta^{2}=.05$, (see: Fig. 2). For the category "Integrated" (PL $-\mathrm{FR})$ the main effect was significant $F(2,163)=3.11, p=.047$; $\eta^{2}=.04$. The mean score for integrated identity was the highest among secondary school students in France $F(2,167)=5.66, p=.004, \eta^{2}=.06$. French language students in Poland had the lowest score in the category "Distinct PL" $F(2,163)=13.13, p<.001, \eta^{2}=.14$. An extended explorative study is needed to explain these unexpected results and whether they may be related to internalization of positive vs. negative stereotypes towards the two cultures. 


\section{Cultural Identity According to Language Skills}

To answer the research question concerning the relation between cultural identity and language proficiency, we conducted a Pearson's correlation analysis. The statistical analysis revealed a significant correlation between the distinctly Polish identity and French to Polish text translation, $r=-.23$, $p=.01$ (see: Table 4).

Table 4. Cultural identity and language proficiency correlations

\begin{tabular}{lcccc}
\hline & \multicolumn{2}{c}{ Listening } & \multicolumn{2}{c}{ Translation } \\
& French & Polish & PL> FR & FR>PL \\
\hline Integrated PL x FR & -.14 & -.07 & .01 & -.03 \\
Polish Identity & .15 & -.01 & -.09 & $-.23^{*}$ \\
French Identity & -.06 & .01 & -.01 & -.01 \\
Neither PL nor FR & -.03 & .01 & -.01 & -.04 \\
\hline
\end{tabular}

${ }^{*}$ The correlation is significant at the 0.01 level (2-tailed)

\section{Discussion}

The aim of this research paper was to shed light on the link between cultural identity and bilingual proficiency in the context of acculturation. This aim has been partially accomplished. The present paper refers to the study of bilingual proficiency and biculturalism of Poles living in France (first generation and CSI students) and French language students in Poland. The three groups were compared with regard to their contact and personal experience with the two national languages and cultures.

The present study went beyond self-declaration measures and assessed linguistic proficiency which further developed methods used by Benet-Martinez et al. (2002). We explored particular language skills operationalized as (1) language comprehension and (2) bidirectional translation. The conducted analyses revealed structural differences in identity, as well as the bilingual profiles of migrants and foreign language students living in their homeland.

The highest rates of proficiency in French and Polish together were observed in the two migrant groups: CSI students (listening comprehension) and first generation (two-way translation). The presented results suggest a relation between acculturative context and improvement of balanced bilinguality in L1 and L2. The CSI students (Group II) scored similarly in L1 and L2 on the listening comprehension scale, whilst the first generation had similar results in PL and FR on the translation scale (see: Figure 1 and 2). In other words, life as an immigrant creates favorable conditions for second language learning. French language students in Poland (Group III) had the lowest mean scores in French and the highest in Polish on the oral comprehension task. In the same group, 
translation skills from French to Polish were slightly better than in the reverse direction (see: Figure 2).

Concerning cultural identity, we received interesting results at the group level. Cultural identities appear reverse to country of residence: the Polish identity score is highest among immigrant youth in France and the French identity score is highest among Polish students of French language and culture. Also, these identities run counter to language competencies. These results suggest conflicted identity integration, according to the Benet-Martínez et al. (2002) model. Results on the identity scale provided by the CSI students suggest their wish to maintain contact with the traditions of their ancestors. Polish culture seems to attract people's attention. Taking into account the bilingual education policy at CSI, the authors speculate that proficiency in both Polish and French language could play a mediating role and might help in answering the inevitable question posed by young migrants: "Who am I?".

The second area of interest for us was the relation between language proficiency and cultural identity, whether growth of bilingual proficiency is accompanied by increased identification with values perceived as jointly French and Polish, distinctly French, or distinctly Polish. It was assumed that the higher the language proficiency in both languages at the same time, the more one would endorse cultural values viewed as common for the two national milieus. If this line of reasoning had been confirmed, we would have provided non-direct evidence that language influences cultural identity. This assumption was not confirmed. Although French language students in Poland strongly identified with the two cultures (French AND Polish), when it was time for them to complete the oral comprehension task, they scored the lowest in French and the highest in Polish. In the same group, translation skills from French to Polish were slightly better than in the opposite direction (see: Figure 2).

The French language proficiency and cultural identity results in group III suggest that the acquisition of values may lead to language learning. Taking into account that presently English is the prevalent second language (spoken fluently by about a quarter of the world's population, roughly 1.5 billion people, Crystal, 2003)one could suppose that the French language students strongly identify with French culture because of ideological instead of practical reasons. The endorsement of cultural values perceived by the non-migrant Polish high school students as intrinsically French might have driven them to select French language as their major subject at university. The results seem to support this claim. Their mean French identity score, compared to groups I and II leads to the conclusion that identification with values attributed to the French culture may lead to language learning. With the highest indices of French identity and the lowest oral comprehension skills students in Poland might underestimate the difficulties faced by migrants. Their identification could change with the experience of life in France and the necessity to search for housing and employment as a foreigner. 
Weinreich \& Saunderson's (2005) Identity Structure Analysis (ISA) theory may also contribute to explaining the results. Social and personal aspirations often are core dimensions of a person's identity. The students in Poland may have formed idealistic identifications with significant others who had ties to French culture and language and who have had influence over their personal well-being. Accordingly, the students may wish to emulate their prized features, including knowledge of the language and life according to western values. Thus, Polish students' choice to study the language of Voltaire is a rather deliberate and idealistic decision motivated by such factors as: esteem/prestige, fascination, admiration or simply the high status of the French language (Lambert, Mallea, $\&$ Young, 1984).

Also, these results may exemplify what Cheng, Lee, and Benet-Martínez (2006) have called the reverse priming or contrast effect. In 2007, Osińska also obtained a similar reverse-priming effect by using a shortened version of the CVSQ (20 questions) among Polish-American students at the American School of Warsaw (ASW, Boski, 2009). In the Polish language/cultural symbol priming condition, ASW students scored significantly lower on Polish value endorsement as opposed to American value endorsement. In the American priming condition, identification with distinctly Polish and distinctly American values was equal.

In the past, contrastive results of the CVSQ have been interpreted as possibly resulting from respondents' feelings of inferiority towards the Polish culture, or their depreciation of it (Boski, 2009). Cheng, Lee, and Benet-Martínez (2006) also suggest that biculturals may internalize one culture's negative stereotypes towards the other or towards itself.

\section{Limitations and further research}

More research is needed to identify the cognitive and affective factors necessary for the contrast effect to take place. The concept of identity may need to be redefined, taking into account not only personal identification with the ethnic/national group(s) but also whether the group(s) is accepting of the member (I am/not: Polish as viewed by other Poles, French as viewed by other French people, Polish as viewed by French people, French as viewed by Poles). Also, in order to more extensively ascertain whether bilingual skills (oral production, writing) are functionally linked to cultural identity development, a longitudinal study is needed. This will be the objective that we are going to achieve in forthcoming studies.

In order to go beyond self-declarative bilingual assessment, the authors applied the bi-directional translation method. Despite its incontestable merits (i.e. assessment of writing skills), one should be careful interpreting the results. While a bilingual person may possess natural translation skills (Malakoff \& Hakuta, 1991), this particular competence is the subject of translation studies, not bilingualism studies. Also, when comparing and interpreting the results 
of these three groups, one should keep in mind the demographic differences (age, gender ratio, initial contact with the French and Polish languages). In order to broaden the scope of the present research, future studies should apply measures for assessing other linguistic skills not explored here (reading, speaking), as well as the harmonious vs. conflictual bilingual identity integration distinction (Benet-Martínez et al., 2002). In this study, we focus on French-Polish bilingualism but the possibilities to study other language pairs are still open.

\section{Acknowledgements}

We are extremely grateful to Joanna M. Kwiatowska for her valuable comments on this and the previous version of this paper.

\section{References}

Benet-Martínez, V., Leu, J., Lee, F., \& Morris, M. W. (2002). Negotiating biculturalism cultural frame switching in biculturals with oppositional versus compatible cultural identities. Journal of Cross-Cultural Psychology, 33(5), 492-516. doi:10.1177/0022022102033005005

Benet-Martínez, V., Lee, F., \& Leu, J. (2006). Biculturalism and cognitive complexity expertise in cultural representations. Journal of Cross-Cultural Psychology, 37(4), 386-407. doi:10.1177/0022022106288476

Bond, M. H. (1983). How language variation affects inter-cultural differentiation of values by Hong Kong bilinguals. Journal of Language and Social Psychology, 2(1), 57-66. doi:10.1177/0261927X8300200104

Boski, P., Jarymowicz, M., \& Malewska-Peyre, H. (1992). Tożsamość a odmienność kulturowa [Identity and cultural difference]. Warszawa: Instytut Psychologii PAN.

Boski, P. (2006). Humanism-materialism centuries -long polish cultural origins and 20 years of research in cultural psychology. In: U. Kim, K-S. Yang, \& K-K. Hwang (Eds.), Indigenious and Cultural Psychology. New York, NY : Springer.

Boski, P. (2008). Five meanings of integration in acculturation research. International Journal of Intercultural Relations, 32(2), 142-153. doi:10.1016/j.ijintrel.2008.01.005

Boski, P. (2009). Kulturowe ramy zachowań społecznych. Podręcznik psychologii międzykulturowej [Social behavior in cultural context. Handbook of crosscultural psychology-in Polish]. Warsaw: PWN Scientific Publishers.

Boski, P., \& IbenYouseff, K. (2012). Consequence of linguitic frame switching: cognitif and emotional shifts in blingual Tunisians. Psychology of Language and Communication, 16(2), 143-163. doi:10.2478/v10057-012-0011-y 
Burkat, A., Jasińska, A., Szymkiewicz, A., \& Małolepsza, M. (2008). Hurra!!! Po polsku Test kwalifikacyjny [Hurra!!! In Polish Qualification Test]. Kraków: Prolog.

Chen, S. X., Benet-Martínez, V., \& Harris Bond, M. (2008). Bicultural identity, bilingualism, and psychological adjustment in multicultural societies: immigration-based and globalization-based acculturation. Journal of Personality, 76(4), 803-838. doi:10.1111/j.1467-6494.2008.00505.x

Cichocka, A., Bilewicz, M., Jost, J. T., Marrouch, N., \& Witkowska, M. (2016). On the grammar of politics - or why conservatives prefer nouns. Political Psychology, 37(6), 799-815. doi:10.1111/pops.12327

Crystal, D. (2003). English as a global language. Cambridge: Cambridge University Press.

Cousins, S. D. (1989). Culture and Self-perception in Japan and the United States. Journal of Personality \& Social Psychology, 56(1), 124-131.

Daszczuk, S. (2012). Działalność edukacyjno-kulturalna Szkoły Polskiej w Lyonie. [Polish school In Lyon: educative and cultural mission]. Kraków: Akademia Ignatianum (Unpublished MA thesis).

Dębski, R. (2009). Dwujęzyczność angielsko-polska w Australii [English-Polish bilinguality in Austalia]. Kraków: WUJ.

Dollez, C., \& Pons, S. (2014). AlterEgo 4. Paris: Hachette.

Hamers, J. F., \& Blanc, M. (2000). Bilinguality and bilingualism. Cambridge: Cambridge University Press.

Herling, G. (1996). A world apart: imprisonment in a soviet labor camp during World War II. Kraków: Penguin.

Kashima, E. S., \& Kashima, Y. (1998). Culture and language: The case of cultural dimensions and personal pronoun use. Journal of Cross-Cultural Psychology, 29(3), 461-486. doi:10.1177/0022022198293005

Lambert, W., Mallea, J., \& Young, J. C. (1984). Culture and language as factors in learning and education. In J. Mallea \& J. C. Young (Eds.), Cultural Diversity and Canadian Education: Issues and Innovations (pp. 233-264). Ottawa: McGill-Queen's Press - MQUP.

Laskowski, R. (2013). Język a tożsamość etniczna. Kształtowanie się poczucia narodowego młodej polskiej diaspory $\mathrm{w}$ warunkach wielokulturowości [Language and ethnic identity. Ethnic identity of young Polish diaspora in a multicultural society]. LingVaria, 16(2), 77-93. doi:10.12797/ LV.08.2013.16.05

Laskowski, R., Czelakowska, A., \& Wiraszka, Ł. (2015). Language Maintenance - Language Attrition: The Case of Polish Children in Sweden. Frankfurt am Main: Peter Lang GmbH, Internationaler Verlag der Wissenschaften.

Malakoff, M. E., \& Hakuta, K. (1991). Translation skill and metalinguistic awareness in bilinguals. In E. Bialystok (Ed), Language processing in bilingual children. (pp. 141-166). New York, NY: Cambridge University Press. doi:10.1017/CBO9780511620652.009 
Markus, H. R., \& Kitayama, S. (1991). Culture and the Self: Implications for cognition, emotion, and motivation. Psychological Review, 98(2), 224-253.

Matczak, E. (2008). La section polonaise à la Cité Scolaire Internationale de Lyon : une alternative à une enseignement classique? [The Polish section at the International School of Lyon: an alternative to traditional education?]. In A. Grudzinska \& K. Siatkowska-Callebat (Eds.), L'enseignement du Polonais en France. (pp. 35-58). Paris: Institut d'études Slaves.

Miodunka, W. (2003). Bilingwizm polsko-portugalski w Brazylii [PolishPortuguese Bilingualism in Brazil]. Kraków: Universitas.

Nisbett, R. E., \& Miyamoto, Y. (2005). The influence of culture: Holistic versus analytic perception. Trends In Cognitive Sciences, 9(10), 467-473. doi:10.1016/j.tics.2005.08.004

Osińska, A. (2007). Identity switch among Polish-American bicultural youths. Warsaw: SWPS University [Unpublished MA thesis].

Pavlenko, A., \& Blackledge, A. (2004). Negotiation of identities in multilingual contexts. Clevedon: Multilingual Matters.

Smolicz, J. (1981). Core values and cultural identity. Ethnic \& Racial Studies, 4(1), 75.

Smolicz, J. (1999). Wspótkultury Australii [The Co-culture of Australia]. Warszawa: Oficyna Naukowa.

Thomas, W. I., \& Znaniecki, F. (2010). The Polish peasant in Europe and America. In R. A. LeVine (Ed), Psychological anthropology: A reader on self in culture. (pp. 18-22). Singapore: Wiley-Blackwell.

Uz, I. (2014). Individualism and first person pronoun use in written texts across languages. Journal of Cross-Cultural Psychology, 45(10), 1671-1678. doi:10.1177/0022022114550481

Weinreich, P., \& Saunderson, W. (2005). Analysing identity: Cross-cultural, societal and clinical contexts. New York, NY: Routledge.

Wierzbicka, A. (1997). Understanding Cultures through their key words: English, Russian, Polish, German, and Japanese. Oxford: University Press.

Wróblewska-Pawlak, K. (2014). O naturalnej dwujęzyczności i przekazywaniu języka dzieciom w sytuacji imigracji [On natural bilingualism and transmission of language to children in the situation of immigration]. LingVaria, 17(1), 239-250.doi:10.12797/LV.09.2014.17.14 


\section{Annex A}

Examples of committed errors in French to Polish text translation and its evaluations.

\begin{tabular}{|c|c|c|c|}
\hline \multirow[t]{2}{*}{0.25} & $\begin{array}{c}\text { „J'habite avec ma } \\
\text { famille dans le quartier } \\
\text { populaire...” }\end{array}$ & $\begin{array}{c}\text { „Żyję z moją rodziną } \\
\text { w popularnej dzielnicy” }\end{array}$ & $\begin{array}{l}\text { „Mieszkam wraz z } \\
\text { moją rodziną w } \\
\text { zwyczajnej dzielnicy” }\end{array}$ \\
\hline & $\begin{array}{c}\text { „dans le quartier } \\
\text { populaire..." }\end{array}$ & „w znanej dzielnicy” & $\begin{array}{c}\text { „...w zwyczajnej } \\
\text { dzielnicy" }\end{array}$ \\
\hline 0.5 & $\begin{array}{c}\text { „En tant que l'adepte } \\
\text { d'association” }\end{array}$ & $\begin{array}{c}\text { adept } \\
\text { stowarzyszenia" }\end{array}$ & $\begin{array}{c}\text { „Jako członek } \\
\text { stowarzyszenia” }\end{array}$ \\
\hline \multirow[t]{2}{*}{0.75} & „dans le département,” & "w wydziale," & „w departamencie," \\
\hline & $\begin{array}{l}\text { "Mes engagements } \\
\text { veulent contribuer à la" }\end{array}$ & $\begin{array}{l}\text { „Moje zaangażowanie } \\
\text { może uczestniczyć” }\end{array}$ & $\begin{array}{c}\text { „Moim zaangażowaniem } \\
\text { pragnę wpłynąć na” }\end{array}$ \\
\hline 1.0 & $\begin{array}{c}\text { „J'habite avec ma } \\
\text { famille dans le quartier } \\
\text { populaire..." }\end{array}$ & $\begin{array}{c}\text { „Ja i moja rodzina } \\
\text { pochodzimy czwartego } \\
\text { stanu społecznego" }\end{array}$ & $\begin{array}{c}\text { „Wraz z rodziną } \\
\text { mieszkam w } \\
\text { zwyczajnej dzielnicy” }\end{array}$ \\
\hline
\end{tabular}

Examples of committed errors in Polish to French text translation and its evaluations.

\begin{tabular}{|c|c|c|c|}
\hline 0.25 & $\begin{array}{l}\text { „nie robię nic } \\
\text { ciekawego," }\end{array}$ & $\begin{array}{l}\text {,je ne fais pas rien } \\
\text { d'interrésant" }\end{array}$ & $\begin{array}{l}\text {,je ne fais rien } \\
\text { d'interrésant" }\end{array}$ \\
\hline 0.5 & $\begin{array}{l}\text { „Mój szef też jest } \\
\text { ambitny i wrażliwy.” }\end{array}$ & $\begin{array}{l}\text { „Mon patron est } \\
\text { ambitieux et }\end{array}$ & $\begin{array}{c}\text { „Mon patron est } \\
\text { ambitieux et sensible.” }\end{array}$ \\
\hline 0.75 & „Mój szef” & „Mon propriètaire...." & „Mon patron” \\
\hline 1.0 & $\begin{array}{c}\text { „dostałam wreszcie } \\
\text { staż w" }\end{array}$ & $\begin{array}{c}\text {,j'ai donné un stage } \\
\text { dans" }\end{array}$ & $\begin{array}{l}\text {,j'ai enfin obtenu } \\
\text { un stage dans" }\end{array}$ \\
\hline
\end{tabular}




\section{The endnote: Texts used in translation task}

French text (i): J'habite avec ma famille dans le quartier populaire. Mes engagements veulent contribuer à la transformation de la société vers plus d'égalité, de fraternité et de solidarité. Je participe à travers mes différentes responsabilités associatives et mon travail d'enseignant à la construction d'un monde où chacun ait une place. En tant que l'adepte d'association « Verts » depuis 1998, je me bats pour que l'image de notre association, dans le département comme dans la ville, se transforme en prenant en compte les idées de l'écologie.

Polish text (ii): Przepraszam, że nie pisałam tak długo, ale dwa tygodnie temu dostałam wreszcie staż w telewizji. Jako stażystka nie robię nic ciekawego, ale ludzie są tu fantastyczni! Otwarci i dynamiczni, pracowici i zdecydowani. Bardzo podoba mi się atmosfera w pracy. Mój szef też jest ambitny i wrażliwy. Zawsze mogę z nim pogadać o moich problemach. A Ty? Co słychać u Ciebie w pracy? Mam nadzieję, że jesteś tak samo zadowolona jak ja. Czekam na odpowiedz. Ewa 